\title{
Functional and anatomical analysis of the anorectum of female scleroderma patients at a center for pelvic floor disorders
}

\author{
Rodrigo Ambar PINTO, Isaac José Felippe CORRÊA NETO, Sérgio Carlos NAHAS, \\ Leonardo Alfonso BUSTAMANTE LOPES, Carlos Walter SOBRADO JÚNIOR and Ivan CECCONELLO
}

\begin{abstract}
Background - Scleroderma or progressive systemic sclerosis is characterized by a chronic inflammatory process with proliferation of fibrous connective tissue and excessive deposition of collagen and extracellular matrix in the skin, smooth muscle, and viscera. The smooth muscle most involved in scleroderma is that of the esophagus, and dysphagia is the most commonly reported symptom. However, the internal anal sphincter may also be impaired by degeneration and fibrosis, leading to concomitant anal incontinence in scleroderma patients. These patients may neglect to complain about it, except when actively questioned. Objective - To assess anorectal function and anatomy of female scleroderma patients with symptoms of anal incontinence through Cleveland Clinic Florida Fecal Incontinence Score (CCFIS), anorectal manometry and endoanal ultrasound at the outpatient clinic of colorectal and anal physiology, Clinics Hospital, University of São Paulo Medical School (HC-FMUSP). Methods - Female scleroderma patients were prospectively assessed and questioned as to symptoms of anal incontinence. The anorectal manometry and endoanal ultrasound results were correlated with clinical data and symptoms. Results - In total, 13 women were evaluated. Their mean age was 55.77 years $( \pm 16.14 ; 27-72$ years) and their mean disease duration was 10.23 years $( \pm 6.23 ; 2-23$ years). All had symptoms of fecal incontinence ranging from 1 to 15. Seven (53.8\%) patients had fecal incontinence score no higher than 7; three (23.1\%) between 8 and 13; and three (23.1\%) 14 or higher, corresponding to mild, moderate, and severe incontinence, respectively. Ten $(76.92 \%)$ patients had hypotonia of the internal anal sphincter. Three-dimensional endoanal ultrasound showed tapering associated with muscle atrophy of the internal sphincter in six cases and previous muscle defects in three cases. Conclusion - A functional and anatomical impairment of the sphincter is an important factor to assess in patients with progressive systemic sclerosis and it should not be underestimated.
\end{abstract}

HEADINGS - Systemic scleroderma. Fecal incontinence. Manometry. Ultrasonography.

\section{INTRODUCTION}

Anal incontinence is defined as the involuntary and recurrent passage of stool or flatus through the anal canal ${ }^{(1-3)}$. Its etiology is multifactorial; the disorder has a significant impact on the quality of life due to physical and psychological impairments ${ }^{(4-6)}$. It is the second leading cause of hospitalization among the elderly in the United States ${ }^{(7,8)}$. The estimated incidence rate lies between $2 \%$ and $7 \% \%^{(3)}$, but it may go up as high as $13.6 \%$ among those over 65 years of age ${ }^{(9)}$. However, it should be emphasized that these rates are fairly underestimated ${ }^{(10)}$ since $50 \%$ to $70 \%$ of the patients with fecal incontinence do not discuss the disorder with their doctors ${ }^{(1,12)}$. Therefore, research on this dysfunction is imperative, especially with respect to patients with associated risk factors.

Deterioration of the mechanisms of anal continence is known to occur mainly in the elderly population. These mechanisms include muscle atrophy and denervation processes, which lead to reduction in intra-anal pressures, impairment of the functional reservoir mechanism of the rectum (reduced capacity and com- placency), and diminished rectal sensitivity. Furthermore, the onset of systemic diseases, chiefly endocrine, neurological, and gastrointestinal disorders, is capable of triggering or aggravating incontinence symptoms in the elderly ${ }^{(13)}$.

Scleroderma or progressive systemic sclerosis is characterized by a chronic inflammatory process with proliferation of fibrous connective tissue and excessive deposition of collagen and extracellular matrix in the skin, smooth muscle, and viscera ${ }^{(14,15)}$. The smooth muscle most involved in scleroderma is that of the esophagus, and dysphagia is the most commonly reported symptom. However, the internal anal sphincter may also be compromised by degeneration and fibrosis, leading to concomitant anal incontinence in scleroderma patients. These patients may neglect to complain about it, except when actively questioned ${ }^{(16)}$.

The esophageal disorder in scleroderma has been the focus several studies, which point to impairment of the organ in 50\% to $80 \%$ of the patients ${ }^{(17)}$. Nevertheless, analysis of the anorectal sphincter complex involvement is much less developed, as evidenced by the restricted number of studies. 
Filling the gap, Lock et al. ${ }^{(14)}$ consecutively analyzed a group of 26 scleroderma patients, four of whom were male. The mean age of the group was 56 years (17-77 years). The authors found that only three $(11.5 \%)$ of the patients had complained about anorectal dysfunction with anal incontinence and they were all female. On the other hand, Rose et al. ${ }^{(18)}$ emphasized that anorectal involvement in scleroderma occurs in approximately $50 \%$ of the cases. Likewise, Trezza et al. ${ }^{(19)}$ reported that $38 \%$ of the scleroderma patients complained of fecal incontinence to some degree.

This study aimed to assess the anorectal function and anatomy of female scleroderma patients with symptoms of fecal incontinence through Cleveland Clinic Florida Fecal Incontinence Score (CCFIS), anorectal manometry and endoanal ultrasound at the outpatient clinic of colorectal and anal physiology, University of São Paulo School of Medicine (HC-FMUSP).

\section{METHODS}

Thirteen female scleroderma patients were prospectively assessed and questioned as to symptoms of anal incontinence. All patients underwent anorectal manometry and endoanal ultrasound.

The questionnaire on anal incontinence symptoms from the Cleveland Clinic Florida $(\mathrm{CCF})^{(20)}$ was administered and the patients' comorbidities (e.g., diabetes and obesity), parity, and history of anorectal surgery were analyzed.

To prepare for the tests, the patients underwent a rectal bowel enema with a $12 \%$ glycerin solution $(250-500 \mathrm{~mL})$ performed at least three hours before the procedures.

For the anorectal manometry test, a device from Alacer Biomé$\operatorname{dica}^{\circledR}$ (São Paulo, SP, Brazil) and an 8-channel radial catheter were employed. Prior to the introduction of the catheter, every patient underwent a proctologic examination. It consisted of an inspection and a rectal digital examination with the right index finger for a subjective assessment of the anal sphincters and confirmation that the rectal ampulla was empty of fecal content.

Subsequently, a gel-lubricated catheter was introduced as far as six centimeters from the anal verge and then, employing the station pull through technique, the device was withdrawn at onecentimeter increments with each station held for about 30 seconds. This is a technique routinely performed at our clinic and at most national and international centers. The resting and squeeze pressures, rectoanal inhibitory reflex, rectoanal sensation, and rectal capacity were measured.

The endoanal ultrasound was performed with a three-dimensional BK Medical ${ }^{\circledR}$ Ultraview 800 machine (Mileparken 34, DK2730 Herlev, Denmark) and a 2050 transducer with the patient in left lateral decubitus with flexed limbs. Scanning was performed in the craniocaudal direction for identification of the puborectalis muscles and internal and external anal sphincter muscles and for measurement of the length of the perineal body from the examiner's index finger in the vaginal introitus. The normal values and ranges for the thickness of the internal and external anal sphincters were within $1.8 \mathrm{~mm}$ and $3.2 \mathrm{~mm}$ and within $6.0 \mathrm{~mm}$ and $12 \mathrm{~mm}$, respectively. Values above or below these ranges were either considered hypertrophy or atrophy.

The anorectal manometry test results were compared to the standard values obtained from the international literature ${ }^{(20-23)}$. The measurements of the internal and external anal sphincters were contrasted with those within the normal limits for three-dimensional endoanal ultrasound according to Murad-Regadas et al. ${ }^{(24)}$.

\section{RESULTS}

Of the 386 scleroderma patients being followed up at the rheumatology outpatient clinic of the Clinics Hospital, University of São Paulo School of Medicine in 2016, 36 exhibited intestinal change, and 13 of these were evaluated. The mean age was 55.77 years $( \pm 16.14 ; 27-72$ years $)$ and the mean duration of disease was 10.23 years $( \pm 6.23 ; 2-23$ years). The symptoms of anal incontinence were in the 1 to 15 range according to the fecal incontinence CCFIS $(0-20)^{(20)}$. TABLE 1 displays a summary of the scleroderma patients' clinical data.

TABLE 1. Clinical parameters of the patients with scleroderma.

\begin{tabular}{|c|c|}
\hline Parameter & Result \\
\hline Number of patients & 13 \\
\hline Mean age & $55.77 \pm 16.14$ years $(27-82$ years $)$ \\
\hline Mean duration of scleroderma & $10.23 \pm 6.23$ years $(2-23$ years $)$ \\
\hline $\begin{array}{l}\text { Mean duration of anal } \\
\text { incontinence }\end{array}$ & $4.58 \pm 8.72$ years $(1-15$ years $)$ \\
\hline \multicolumn{2}{|l|}{$\begin{array}{l}\text { Clinical manifestations of the } \\
\text { disease }\end{array}$} \\
\hline & CREST - 9 \\
\hline & Pulmonary hypertension/Fibrosis -8 \\
\hline & Reynaud -7 \\
\hline & Esophageal - 11 \\
\hline & A combination of 2 or more -10 \\
\hline \multicolumn{2}{|l|}{ Obstetric history } \\
\hline & Vaginal deliveries - 6 \\
\hline & Mean of vaginal deliveries -2.2 \\
\hline & Cesarean deliveries -3 \\
\hline & Nulligravida -4 \\
\hline
\end{tabular}

CREST: Calcinosis, Reynaud, Esophageal involvement, Sclerodactyly, Teleangectasia.

Seven $(53.8 \%)$ patients had a fecal incontinence score no higher than 7 , three $(23.1 \%)$ between 8 and 13 , and three $(23.1 \%) 14$ or higher, corresponding to mild, moderate, and severe anal incontinence, respectively.

None of the patients had diabetes mellitus, two $(16.7 \%)$ were obese, and $11(84.61 \%)$ were symptomatic and had esophageal involvement. Four $(30.77 \%)$ patients were nulliparous. One patient had previously undergone colorectal surgery but she had no history of anorectal surgery. Digital rectal examination revealed low resting pressure in seven $(53.85 \%)$ patients.

The anorectal manometry data (TABLE 2 ) showed a mean resting pressure of $32.49 \mathrm{~mm} \mathrm{Hg}( \pm 18.1 ; 7.2-62.7 \mathrm{~mm} \mathrm{Hg})$ and hypotonia in the internal anal sphincter in $10(76.92 \%)$ patients. Of these, four had severe hypotonia with pressures no higher than $20 \mathrm{~mm} \mathrm{Hg}$, two had moderate hypotonia with pressures between 20 and $30 \mathrm{~mm} \mathrm{Hg}$, and four had mild hypotonia with pressures between 30 and $40 \mathrm{~mm} \mathrm{Hg}$. The functional anal canal was $2.2 \mathrm{~cm}$ long on average, and it was absent in the four patients whose resting pressures were lower than or equal to $20 \mathrm{~mm} \mathrm{Hg}$. The mean squeeze pressure was $70.88 \mathrm{~mm} \mathrm{Hg}(20.0-126.4 \mathrm{~mm} \mathrm{Hg})$, and three $(23.04 \%)$ patients had hypotonia of the external anal sphincter. The mean total squeeze sphincter pressure was $110.46 \mathrm{~mm} \mathrm{Hg}( \pm 17.84$; $90.5-140)$. Mean rectal sensitivity was $71.33( \pm 60.71 ; 14-155)$ and 
TABLE 2. Mean values of anorectal manometry and comparison with normal limits.

\begin{tabular}{lcc}
\hline & Mean values & Alterations \\
\hline Resting pressures & $\begin{array}{c}32.49 \pm 18.1 \mathrm{~mm} \mathrm{Hg} \\
(7.2-62.7 \mathrm{~mm} \mathrm{Hg})\end{array}$ & $\begin{array}{c}\text { Hypotonia in } \\
\text { 76.92\% of the cases }\end{array}$ \\
Total squeeze & $110.46 \pm 17.84 \mathrm{~mm} \mathrm{Hg}$ & Hypotonia in \\
pressures & $(90.5-140 \mathrm{~mm} \mathrm{Hg})$ & $23.04 \%$ of the cases \\
& $71.33 \pm 60.71 \mathrm{~mL}$ & Reduction in \\
Rectal sensitivity & $(14-155 \mathrm{~mL})$ & $53.85 \%$ of the cases \\
& $154.17 \pm 49.01 \mathrm{~mL}$ & Reduction in \\
Rectal capacity & $(87-270 \mathrm{~mL})$ & $7.69 \%$ of the cases \\
\hline
\end{tabular}

it was reduced in seven $(53.85 \%)$ cases. On the other hand, mean rectal capacity was $154.17 \mathrm{~mL}( \pm 49.01 ; 87-270)$ and it was reduced in only one $(7.69 \%)$ patient.

The three-dimensional endoanal ultrasound results showed tapering associated with the muscle atrophy of the internal sphincter in 6 cases and with a previous muscle defect in three $(69.23 \%)$ cases. Analysis of the acoustic characteristics of the external anal sphincter revealed defects in the sphincter in three cases, co-occurring with the defects of the internal anal sphincter. There was only one case of degenerative diffuse muscular atrophy.

TABLE 3 exhibits the functional and anatomical correlation between anorectal manometry and endoanal ultrasound. Only one of the three patients with normal internal sphincter pressure showed no ultrasound alterations; the mean incontinence score of these patients was 6.67 . Of the three patients with mild hypotonia, one alone displayed changes in the internal sphincter on the ultrasound; the mean incontinence score of this group was 8.33. Only one of the three patients with moderate hypotonia of the internal sphincter had no anatomical alterations; the mean incontinence score of this trio was also 8.33. The four patients with severe hypotonia of the internal sphincter exhibited anatomical changes in the sphincter, and their mean incontinence score was 9.25 .

TABLE 3. Anatomical and functional correlation between internal sphincter pressures, anatomical changes, and incontinence scores.

\begin{tabular}{lccc}
\hline Patient & $\begin{array}{c}\text { Hypotonia of the } \\
\text { internal sphincter } \\
\text { (no/mild/ } \\
\text { moderate/severe) }\end{array}$ & $\begin{array}{c}\text { Ultrasound } \\
\text { changes }\end{array}$ & $\begin{array}{c}\text { CCF } \\
\text { incontinence } \\
\text { score }\end{array}$ \\
\hline Patient 4 & No & Yes & 14 \\
Patient 11 & No & No & 5 \\
Patient 13 & No & Yes & 1 \\
Patient 1 & Mild & No & 7 \\
Patient 2 & Mild & Yes & 8 \\
Patient 3 & Mild & No & 10 \\
Patient 6 & Moderate & Yes & 14 \\
Patient 7 & Moderate & Yes & 8 \\
Patient 9 & Moderate & No & 3 \\
Patient 5 & Severe & Yes & 15 \\
Patient 8 & Severe & Yes & 7 \\
Patient 10 & Severe & Yes & 5 \\
Patient 12 & Severe & Yes & 10 \\
\hline
\end{tabular}

CCF: Cleveland Clinic Florida.

\section{DISCUSSION}

Although the incidence of anorectal function impairment in scleroderma patients is not insignificant, it is usually not reported by them ${ }^{(25)}$ - except when they are questioned by the physician assistant - despite the steep decline in the quality of life caused by fecal leakage ${ }^{(15,19)}$. The anorectal region is estimated to be affected in $50 \%$ to $70 \%$ of scleroderma patients. Of these, $20 \%$ to $39 \%$ will experience some degree of anal incontinence ${ }^{(26-28)}$, which will unfavorably impact their lives ${ }^{(29)}$.

The pathogenesis of gastrointestinal dysfunctions in scleroderma is rooted in myogenic and neural abnormalities with atrophy of the muscle layer - brought on by vascular ischemia - and neural plexus disorders resulting from variable degrees of lamina propria fibrosis ${ }^{(15)}$. The anorectal sphincter complex exhibits fibrosis and dysfunction primarily of the internal anal sphincter, which consists of smooth muscle. Nonetheless, the correlations involving pathology, manometric findings, and clinical symptoms reported by patients are still unclear.

Trezza et al. ${ }^{(19)}$ reported that approximately $40 \%$ of the scleroderma patients suffered from anal incontinence, which was further compounded by diarrhea and accelerated colonic transit. Fynne et al. ${ }^{(25)}$, in a recent study involving 20 scleroderma patients, found that $70 \%$ had diarrhea and eight $(40 \%)$ had fecal incontinence with a CCFIS over 9. Additionally, the study reported that the anal resting pressure in patients with anal incontinence was significantly lower than that of controls $(P<0.001)$ and scleroderma patients without anal incontinence $(P<0.05)$.

Herrick et al. analyzed anorectal manometric characteristics in 16 scleroderma patients; of these, seven had no colorectal functional symptoms, six had constipation, and three had complaints about diarrhea and/or anal incontinence. The authors reported that the mean resting pressure of patients with no anorectal symptoms was $39.8 \mathrm{~mm} \mathrm{Hg}$ and that of patients with complaints about fecal incontinence was $31.7 \mathrm{~mm} \mathrm{Hg}$. Conversely, the mean squeeze pressure of patients with no anorectal symptoms was $70.1 \mathrm{~mm} \mathrm{Hg}$ as compared to $103.8 \mathrm{~mm} \mathrm{H}$ in patients with fecal incontinence.

Thoua et al. ${ }^{(27)}$ studied 44 scleroderma patients, four $(9.1 \%)$ of whom were male. Twenty-four $(54.5 \%)$ told of symptoms of anal incontinence. When the patients with and without symptoms of anal incontinence were compared, a reduction in resting pressures was found. However, the decrease was not statistically significant.

Finally, in a multicentric study, Richard et al. ${ }^{(30)}$ evaluated 298 scleroderma patients, $87.9 \%$ of whom were female with a mean age of 59.4 years and with symptoms lasting on average for 10.9 years. These data are similar to those in the present study, in which the mean age of the patients was 55.66 years and the mean symptom duration was 10.23 years. Besides, the authors observed that among the factors for anal incontinence in scleroderma patients, age $(P=0.01)$, disease duration $(P=0.01)$, female gender $(P=0.056)$, and transvaginal delivery $(P<0.001)$ should be emphasized when comparing scleroderma patients with and without symptoms of anal incontinence. Furthermore, urinary incontinence was found significantly associated with symptoms of fecal leakage or flatus $(P<0.001)$ and with intestinal constipation $(P<0.001)$.

In the present study, the anorectal manometric data of scleroderma patients with previously known symptoms of anal incontinence revealed hypotonia of the anal sphincter muscle in $76.92 \%$ of the cases with a dysfunction of voluntary contraction pressures, corresponding to $23.04 \%$ of the patients. Still, in the cases 
of moderate or severe anal incontinence the mean resting pressure was $25.3 \mathrm{~mm} \mathrm{Hg}$, whereas in the women with symptoms of mild anal incontinence, it was $38.7 \mathrm{~mm} \mathrm{Hg}$.

Three-dimensional ultrasound showed a correlation between anatomical and functional changes in 9 cases $(69.23 \%)$, as well as evidence of flaws, atrophies, or irregularities primarily related to the internal anal sphincter. Moreover, it showed a correlation between anatomical alterations and manometric results (low resting pressures), along with a higher incontinence score in the patients with more severe hypotonia in the internal sphincter.

A limiting factor in this study is the small sample size, attributed to the characteristics of the colorectal-anal physiology clinic which is a referral center. Nevertheless, the symptom duration of the disease and the use of a parameter validated in the anal incontinence research enhance the study.

\section{CONCLUSION}

The functional and anatomical evaluation of women with scleroderma and symptoms of anal incontinence confirmed hypotonia of the internal anal sphincter and anatomical disorders in most cases. It also showed a correlation between manometric dysfunctions and severity of anal incontinence. A functional and anatomical impairment of the sphincter is an important factor to assess in patients with progressive systemic sclerosis and it should not be underestimated.

\section{ACKNOWLEDGEMENT}

The authors thank Dr. Diego Fernandes Maia Soares for his equal contribution to this article.

\section{Authors' contribution}

Pinto RA: patient recruitment, data collection, examined all patients, paper write. Corrêa Neto IJF: helped in patient recruitment, data review, review of statistical analysis and literature review. Nahas SC: supervision of patient recruitment, exams, supervision of literature review and paper review. Bustamante Lopez LA: referred patients, tables confection and review, paper review. Sobrado Junior CW: data review and support of statistical analysis, tables review. Cecconello I: senior author, supervised all work during the whole process and paper final review.

Pinto RA, Corrêa Neto IJF, Nahas SC, Bustamante Lopes LA, Sobrado Junior CW, Cecconello I. Análise funcional e anatômica anorretal de pacientes femininas portadoras de esclerodermia em um centro universitário de referência em desordens do assoalho pélvico. Arq Gastroenterol.

RESUMO - Contexto - Esclerodermia ou esclerose sistêmica progressiva caracteriza-se por um processo inflamatório crônico com proliferação e fibrose do tecido conjuntivo e uma deposição excessiva de colágeno e matriz extracelular na pele, musculatura lisa e vísceras. A musculatura lisa mais envolvida é a esofágica e a disfagia é o sintoma mais comumente relatado. Entretanto, o esfíncter anal interno também pode ser acometido por essa degeneração e fibrose ocasionando incontinência anal nos pacientes portadores de esclerodermia. Isso pode ser omitido pelo paciente, exceto quando questionado de forma direta. Objetivo - Analisar a função e anatomia anorretal através do escore de incontinência anal de Cleveland Clinic Florida, manometria anorretal e ultrassom endoanal em pacientes do sexo feminino portadoras de esclerodermia e sintomas de incontinência anal atendidas no ambulatório de Fisiologia Colorretoanal no Hospital das Clínicas da Universidade de São Paulo (HC-FMUSP). Resultados - Treze pacientes do sexo feminino foram avaliadas com média de idade de 55,77 anos ( $\pm 16,14 ; 27-72$ anos) e duração média da doença de 10,23 anos ( $\pm 6,23 ; 2-23$ anos). O índice de incontinência anal teve variação de $1-15$, sendo que sete (53,8\%) pacientes apresentavam índice inferior a 7; três (23,1\%) entre 8 e 13 ; e três $(23,1 \%)$ superior a 14 , correspondendo à incontinência anal leve, moderada e grave, respectivamente. Dez (76,92\%) pacientes apresentavam hipotonia do esfíncter anal interno. O estudo da ultrassonografia endoanal de três dimensões demonstrou afilamento com atrofia do esfíncter anal interno em seis casos e defeito muscular em três pacientes. Conclusão - O prejuízo funcional e anatômico do complexo esfincteriano anorretal é um importante fator a ser analisado em pacientes portadores de esclerose sistêmica progressiva e isso não pode ser subestimado.

DESCRITORES - Escleroderma sistêmico. Incontinência fecal. Manometria. Ultrassonografia.

\section{REFERENCES}

1. Bharucha AE, Zinsmeister AR, Locke GR, Seide BM, McKeon K, Schleck CD, Melton LJ. Prevalence and burden of fecal incontinence: a population-based study in women. Gastroenterology. 2005;129:42-9.

2. Navarro JM, Arroyo Sebastián A, Pérez Vicente F, Sánchez Romero AM, Pérez Legaz J, Serrano Paz P, et al. [Sacral root neuromodulation as treatment for fecal incontinence. Preliminary results]. [Article in Spanish]. Rev. Esp Enferm Dig. 2007;99:636-42.

3. Oliveira L, Jorge JMN, Yusuf S, Habr-Gama A, Kiss D, Cecconelo I. [New treatment modality of anal incontinence: trans-sphincteric silicone injection improved quality of life in 35 incontinent patients]. [Article in Portuguese]. Rev. Bras. Coloproct. 2007;27:167-73.

4. Rockwood TH, Church JM, Fleshman JW, Kane RL, Mavrantonis C, Thorson AG, et al. Fecal Incontinence Quality of Life Scale: quality of life instrument for patients with fecal incontinence. Dis Colon Rectum. 2000;3:9-17.

5. Yusuf SAI. Avaliação da qualidade de vida na incontinência anal: validação do questionário "fecal incontinence quality of life" (FIQL). [Dissertation]. Faculdade de Medicina da Universidade de São Paulo; 2001.
6. Melenhorst J, Koch SM, van Gemert WG, Baeten CG. The artificial bowel sphincter for faecal incontinence: a single centre study. Int J Colorectal Dis. 2008;23:107-11.

7. Gordon PH, Nivatvongs. Principles and Practice of Surgery for the Colon, Rectum and Anus, 3th ed. New York; 2007. Informa Healthcare: 293-332.

8. Lahr C. Evaluation and treatment of incontinence. Pract Gastroenterol. 1998;102:895-901.

9. Aspiroz F. Guía práctica sobre incontinencia anal. Rev Esp Enferm Dig. 2003;95:722-6.

10. Dorcaratto D, Martínez-Vilalta M, Parés D. [Current indications, surgical technique and results of anterior sphincter repair as a treatment of faecal incontinence]. [Article in Spanish]. Cirugía Española. Cir Esp. 2010;87:273-81.

11. Johanson JF, Lafferty J. Epidemiology of fecal incontinence: the silent affliction. Am J Gastroenterol. 1996;91:33-6.

12. Galandiuk S, Roth LA, Greene QJ. Anal incontinence-sphincter ani repair: indications, techniques, outcome. Langenbecks Arch Surg. 2009;394:425-33.

13. Galandiuk S, Roth LA, Greene QJ. Anal Incontinence-sphincter ani repair: indications, techniques, outcome. Langenbecks Arch Surg. 2009;394:425-33. 
14. Lock G, Zeuner M, Lang B, Hein R, Scholmerich J, Holstege A. Anorectal function in Systemic Sclerosis-correlation with esophageal dysfunction? Dis Colon Rectum. 1997:40:1328-35.

15. Souza NM, Williams AD, Wilson HJ, Gilderdale DJ, Coutts GA, Black CM. Fecal incontinence in Scieroderma: assessment of the anal sphincter with Thin-Section Endoanal MR imaging. Radiology. 1998;208:529-35.

16. Zaninotto G, Peserico A, Costantini M, Salvador L, Rondinone R, Roveran A, et al. Oesophageal motility and lower oesophageal sphincter competence in progressive systemic sclerosis and localized scleroderma. Scand J Gastroenterol. 1989;24:95-102.

17. Heyt GJ, Oh MK, Alemzadeh N, Rivera S, Jimenez SA, Rattan S, Cohen S, Dimarino AJ. Impaired rectoanal inhibitory response in scleroderma (systemic sclerosis): an association with fecal incontinence. Dig Dis Sci. 2004;49:1040-5.

18. Rose S, Young MA, Reynolds JC: Gastrointestinal manifestations of scleroderma. Gastroenterol Clin North Am. 1998; 27:563-94.

19. Trezza M, Krogh K, Egekvist H, Bjerring P, Laurberg S: Bowel problems in patients with systemic sclerosis. Scand J Gastroenterol. 1999;34:409-13.

20. Jorge JMN, Wexner SD. Etiology and management of anal incontinence. Dis colon rectum. 1993;36:77-97.

21. Gundling F, Seidl H, Scalercio N, Schmidt T. Schepp W, Pehl C. Influence of Gender and Age on Anorectal Function: Normal Values from Anorectal Manometry in a Large Caucasian Population. Digestion. 2010;81:207-13.

22. Denoya P, Sands DR. Anorectal physiologic evaluation of constipation. Clin Colon Rectal Surg. 2008;21:114-21.
23. Rios CC, Juan RLS, Garcia MDR, Moros ET, Durán FG, Yagüe TM, et al. Differences in the pressures of canal anal and rectal sensitivity in patients with fecal incontinence, chronic constipation and healthy subjects. Rev Esp Enfer Dig. 2010;102:683-90.

24. Regadas SMM, Regadas FSP, Rodrigues LV, Chaves RW, Lima CMM, Lopes LA. Limitações e Detalhes Técnicos do Ultra-Som Endo-Anal no Diagnóstico de Afecções Benignas e Malignas no Canal Anal. Rev bras Coloproct. 2004;24:230-9.

25. Fynne L, Worsoe J, Laurberg S, Krogh K. Faecal incontinence in patients with systemic sclerosis: is an impaired internal anal sphincter the only cause? Scand $\mathbf{J}$ Rheumatol. 2011;40:462-6.

26. Herrick AL, Barlow JD, Bowden A, Williams N, Hobson AR, Irving M, Jayson MIV. Investigation of anal function in patients with systemic sclerosis. Annals of the Rheumatic Diseases. 1996,55:370-4.

27. Thoua NM, Schizas A, Forbes A, Denton CP, Emmanuel AV. Internal anal sphincter atrophy in patients with systemic sclerosis. Rheumatology. 2011;50:1596-602.

28. Mawdsley AH. Patient perception of UK scleroderma services-results of an anonymous questionnaire. Rheumatology. 2006;45:1573.

29. Franck-Larsson K, Graf W, Ronnblom A. Lower gastrointestinal symptoms and quality of life in patients with systemic sclerosis: a population-based study. Eur J Gastroenterol Hepatol. 2009;21:176-82.

30. Richard N, Hudson M, Gyger G, Baron M, Sutton E, Khalidi N, et al. Clinical correlates of faecal incontinence in systemic sclerosis: identifying therapeutic avenues. Rheumatology (Oxford). 2017;56:581-8. 